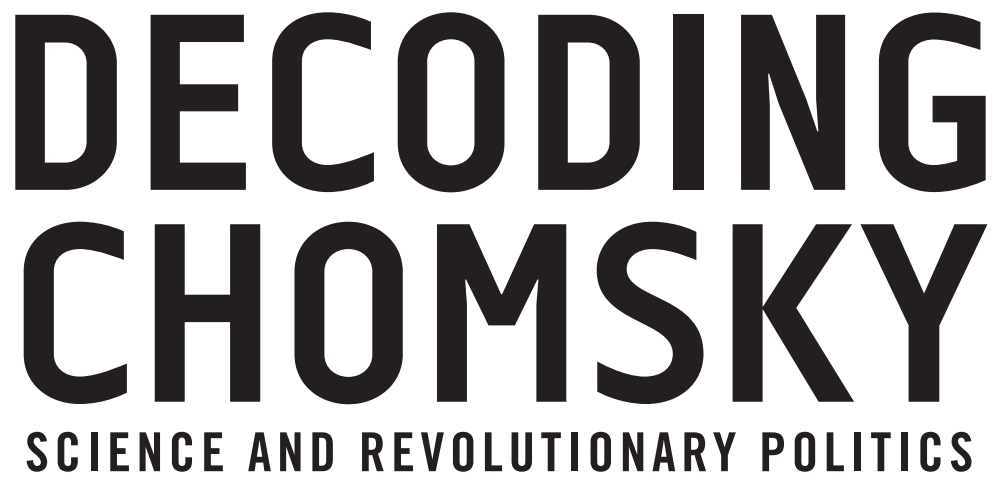

CHRIS KNIGHT

YALE UNIVERSITY PRESS

NEW HAVEN AND LONDON 


\section{DECODING CHOMSKY}

Chris Knight is currently senior research fellow in the Department of Anthropology at University College London, exploring what it means to be human by focusing on the evolutionary emergence of language and symbolic culture. He is the author of Blood Relations: Menstruation and the Origins of Culture (Yale, 1991) among many other publications. His website is www.scienceandrevolution.org.

\section{Further responses to Decoding Chomsky:}

'The whole story is a wreck ... complete nonsense throughout'. Noam Chomsky

'One of the most exciting scholarly books I have read in years ... Decoding Chomsky will be required reading for anyone at all interested in the history of intellectual and political thought since the 1950s.'

David Golumbia, author of The Cultural Logic of Computation

'Simply brilliant. Others have noted the systematic disjunct between Chomsky's Pentagon-funded linguistics and his political dissidence, but this is the first theoretically sophisticated analysis of a chasm between mind and body, theory and practice which has become profoundly symptomatic of postmodern culture as a whole.'

David Hawkes, author of Ideology

'History comes alive via compelling narrative ... Knight is indeed an impressive historian when it comes to recounting the gripping personal histories behind Chomsky's groundbreaking contributions to science and philosophy' Sean O’Neill, American Ethnologist

'This extraordinary book will make uncomfortable reading for some because, while celebrating Chomsky's anti-racist and anti-imperialist politics, Knight reminds us of the other Chomsky, the world-famous linguist [who has been] ... working in one of the Pentagon's most prestigious laboratories.'

Jackie Walker, author of Pilgrim State

'Few disagree that language has been a game-changer for the human species. But just how we came by language remains hotly contested. In Decoding Chomsky, Chris Knight strides into this minefield to bravely replace miraculous leaps and teleology with a proposal that actually makes evolutionary sense.'

Sarah Hrdy, author of Mothers and Others: The Evolutionary Origins of Mutual Understanding 
'Reads like a detective novel. So many of the arguments I found right on the mark, but I would recommend it just for the pleasure of reading Knight's great English prose, particularly his talent for understatement. A truly fantastic work, simply brilliant. I could not put it down.'

Luc Steels, author of The Talking Heads Experiment: Origins of Words and Meanings

'Knight's exploration of Chomsky's politics, linguistics, and intellectual history is unparalleled. No other study has provided such a full understanding of Chomsky's background, intellectual foibles, objectives, inconsistencies, and genius.'

Daniel Everett, author of How Language Began: The Story of Humanity's Greatest Invention

'Chris Knight is to be commended for this engaging and thought-provoking intellectual history of a thesis that remains hotly contested - and the reverberations of which, as he rightly observes, resonate far beyond academia.'

Houman Barekat, Times Literary Supplement

'This book provides a fascinating account of the disconnect and symmetry between Chomsky's value-free science and his science-free politics. Knight roots this in the tension between Chomsky's detestation of the US military and his dependence on military funding for his linguistic research.'

Les Levidow, editor, Science as Culture

'Chris Knight's takedown is brutal and elegant at the same time. His analysis is repeatedly jaw-droppingly good ... Mission accomplished.'

Alex Walter, author of Evolutionary Psychology and the Propositional-attitudes

'Fascinating on so many levels, Knight's critique of an academic demigod is a compelling case study of the institutional, personal, interpersonal, historical and accidental forces shaping one of the major intellectual movements of our time.'

N.J. Enfield, author of How We Talk: The Inner Workings of Conversation

'Intellectually hip and iconoclastic, Decoding Chomsky surveys 1950s McCarthyite politics and 1960s student unrest in order to get a handle on the extraordinary influence of Noam's ideas. If you're a former New Left protestor against university collaboration with the US war machine or a current 21st-century anti-war student, you'll find Knight's chapter on MIT's historical relationship to the Pentagon especially cutting-edge, ground-breaking and informative.'

Bob Feldman, Students for a Democratic Society Steering Committee, Columbia University, 1968 
Copyright (C) 2016 Chris Knight

Preface to the paperback edition @ 2018 Chris Knight

First published in paperback in 2018

All rights reserved. This book may not be reproduced in whole or in part, in any form (beyond that copying permitted by Sections 107 and 108 of the U.S. Copyright Law and except by reviewers for the public press) without written permission from the publishers.

For information about this and other Yale University Press publications, please contact: U.S.Office: sales.press@yale.edu yalebooks.com Europe Office: sales@yaleup.co.uk yalebooks.co.uk

Typeset in Minion Pro by IDSUK (DataConnection) Ltd Printed in Great Britain by Hobbs the Printers, Totton, Hampshire

Library of Congress Control Number: 2016945085

ISBN 978-0-300-22876-2 (pbk)

A catalogue record for this book is available from the British Library. 
To all my grandchildren 
"It is no wonder that "fraternity" has traditionally been inscribed on the revolutionary banner alongside "liberty" and "equality". Without bonds of solidarity, sympathy and concern for others, a socialist society is unthinkable. We may only hope that human nature is so constituted that these elements of our essential nature may flourish and enrich our lives, once the social conditions that suppress them are overcome. Socialists are committed to the belief that we are not condemned to live in a society based on greed, envy and hate. I know of no way to prove that they are right, but there are also no grounds for the common belief that they must be wrong.'

Noam Chomsky, Class Warfare, 1996

'Man is ... an animal which can develop into an individual only in society. Production by isolated individuals outside society ... is as great an absurdity as the idea of the development of language without individuals living together and talking to one another.'

Karl Marx, Grundrisse, 1857

'There was a time when language united people ... "Us! One of us!" rings through the darkness with every word of their shared language. Language unites them like a familiar voice.'

Velimir Khlebnikov, 'Our fundamentals’, 1919 